\title{
Perceptions of Medical Students and EFL Instructors of Their EAP Materials, Challenges and Implications for Iranian EAP Instructors
}

\author{
Gholamreza Hessamy \\ Department of Linguistics and Foreign Languages, Payame Noor University, Iran \\ Masoumeh Mohebi \\ Department of Linguistics and Foreign Languages, Payame Noor University, Tehran, Iran
}

\begin{abstract}
EAP textbooks and materials are probably the most important element in academic English courses in Iran. Therefore, their evaluation can help to identify their strengths and weaknesses, and hence, to improve their quality. The purpose of this study was to examine the perceptions of EFL instructors and medical students of their EAP textbook. It was also an attempt to find out about the challenges they may have in their teaching and learning contexts. To conduct this study, 175 medical students and 25 EFL instructors were selected from four medical universities. The instruments for gathering data were a questionnaire and interview. Statistical $t$-test and MANOVA were used for analyzing the data. The results of quantitative analyses showed that there was no significant difference between the students' and EFL instructors' perceptions of their EAP textbook. However, there were significant differences between their perceptions of six different aspects of the textbook. Moreover, the qualitative data showed that overcrowded classes, lack of appropriate materials to the learners' needs, lack of clear objectives in the EAP context, and shortage of time were the major challenges instructors and students are faced with. In conclusion, although there were positive perceptions of the textbook they use, most of the instructors did not think that it was enough for an EAP course. Besides, they believed that the number of the students in their classes should be reduced, there should be clear objectives for EAP courses, and based on such objectives, relevant materials should be designed and developed.
\end{abstract}

Index Terms - perceptions, EAP textbook, instructors, learners, challenges

\section{INTRODUCTION}

Textbooks play an important role in the realm of general and EAP language programs and are considered the next important element after the teacher (Riazi, 2005). They are an effective resource for self-directed learning, an effective resource for teachers to present materials, a source of reference for learners, a source of ideas and tasks, a syllabus that mirror pre-determined learning objectives, and a support for inexperienced and less confident teachers (Cunningsworth, 1995).

According to Dudley-Evans and St. John (1998), in some situations where English is used as a foreign language, ESP classroom may be the only source of English. Therefore, materials play an important role in exposing learners to the language. They believe that in order to support learning, materials need to be reliable; to improve learning they must engage learners in thinking about and using the language; to motivate and stimulate, they need to be challenging and also reachable; to enhance learners' and instructors' motivation, they should provide variety of activities; and to support mixed abilities, they should provide exercises and tasks at different levels of difficulty. Good EAP materials from Hutchinson and Waters' (1987) perspective are those that suit the needs of teachers, learners and sponsors. They should encourage learners to learn, should contain interesting texts and activities which involve learners in thinking, should provide opportunity for learner to use their existing knowledge and skill, and should have content that both teachers and learners can cope with. They also mention that good materials should provide a clear and coherent unit structure that help both teacher and learner maximize the chances of learning.

While many of the researchers point to the extensive benefits of using ESL/EFL textbooks, there are other researchers have highlighted the disadvantages regarding the use of the textbooks. For example, Swales (1980) believes that EAP textbooks in spite of commercial success suffer from educational failure. He also mentions that the main reason of this failure could be either in the product of the textbook or in the primary user. According to Jones (1990), “...the majority of ESP textbooks are not regionally based but are distributed globally, often as a panacea for all ills" (p. 89). Williams (1983) calls a textbook "a tyrant". He mentions that a textbook can be a tyrant to the teacher who is covering the syllabus, feels that he/she is limited by every item which is presented by the textbook writer. Ansari \& Babayi (2002) also state that no single textbook can be perfect for different groups of learners with differing learning needs and learning styles, topics in a textbook may not be relevant for and interesting to all learners, and a textbook can 
be limiting in the sense that it may inhibit teachers' creativity. Therefore, teachers should have the potential to supplement a textbook with certain materials based on their own specific needs in their own specific situation.

Hutchinson and Waters (1984) believe that many of ESP textbooks have appearance of being content-based rather than language-based. However, there is no guarantee for motivation and interest in content-based materials. In fact, the content of many ESP materials is often only a vehicle for language practice, inadequately integrated with the rest of the materials in terms of subject matter. The learners must be given materials which have the right kind of content and integrated in the right way (Hutchinson \& Waters, 1984).

While argument regarding whether to use textbooks continue, they still maintain enormous popularity and there is a demand for them to grow. It should be mentioned that there has been a movement since 1970's to put the learners at the center of language instruction, and the textbooks are perceived as the most important resources in achieving aims and objectives that have already been set in terms of learners' needs (Brown, 1995, as cited in Litz, 2005). However, they should not determine the aim of the course themselves or become the aim, but they must be at the service of teachers and learners (Brown, 1995, as cited in Litz, 2005). Therefore, we must do our best to establish and apply a wide variety of criteria to assess the textbooks we use in our classroom (Litz, 2005). We must also ensure "that careful selection is made, and the materials selected closely reflect the aims, methods, and values of the teaching program" (Cunningsworth, 1995 , p.7).

\section{THE STUDY}

\section{Rational and Purpose of the Study}

One of the important issues in language learning in general, and EAP in particular, is to examine whether the textbooks are appropriate for a given course and for a particular group of learners in a particular context or not. In this regard, knowing about the learners' and teachers' viewpoints on their textbooks can provide a basis for material evaluation. "Medical Terminology: An illustrated Guide" $5^{\text {th }}$ written by Cohen in 2008, is one of the widely used EAP textbook in medical field in Iranian academic context. Since this book was produced to meet the specific needs of Canadian students of medicine, it seems necessary to examine its effectiveness and usefulness from Iranian students' and instructors' point of views.

By reviewing the literature we found that there are debates regarding the EAP textbooks in Iran. However, most of these discussions were based on textbooks published by SAMT center which is a governmental organization responsible for developing academic textbooks in Iran (e.g. Baleghizadeh \& Rahimi, 2011; Eslami-Rasekh, 2010; Farhady, 2005; Hashemi, Lamir, \& Rezaee-Namjoo, 2011; Razmjoo \& Raissi, 2010; Shamsaee \& Shams, 2010; Shokouhi, 2005; Soleimai, 2005; Tajeddin, 2005; etc.). Few studies focused on textbooks written by native speakers and there was a lack of evaluations made from the perspectives of both teachers and learners. Therefore, the present study was an attempt to evaluate the perceptions of both EFL instructors and medical students of their EAP textbook and also to find out the possible challenges they may have in the teaching and learning process. The finding can have pedagogical implications not only for teachers and learners, but also for EAP material writers, course designers, publishers, and ultimately for those who are decision makers for academic English courses in Iran.

\section{Methodology}

\section{A. Participants}

Both EFL instructors and medical students participated in this study: The sample of instructors included 25 EFL instructors who taught EAP courses at the university. They were 15 men and 10 women between 27-70 years old with teaching experience at university level ranging from two to forty years. All of the instructors were PhD holders in TEFL, English literature, and linguistics. The sample also included a number of 175 students of medicine (57 male and 118 female). Their ages ranged from 18 to 27 years and they were all undergraduates. The availability sampling was used to select the participants from four medical universities (Tehran University of Medical Sciences, Shahid-Beheshti University of Medical Sciences, Tehran Islamic Azad University of Medical Sciences, and Zanjan University of Medical Sciences).

\section{B. Instruments}

In this study, questionnaire and semi-structured interviews were used for obtaining qualitative and quantitative data. Such a method integrates both approaches to provide a much more detailed and comparative picture of what is being investigated. In this study, the qualitative data (interview) was gathered after quantitative data collection in order to deepen our understanding and interpretation of the results and to provide us with information that cannot be readily obtained through questionnaires.

\section{Questionnaire}

The questionnaire used in this study was the modified version of the one used by Balegizadeh and Rahimi (2011) that was originally based on Sheldon (1988) model (Appendix A). It had two parts: part A of the questionnaire contained items asking about the participants' demographic information. Part B of the questionnaire contained 23 likert scale items ranging from 1 (very weak) to 5 (excellent) which asked the participants to express their perceptions of their EAP 
textbooks based on six categories of practical concern, materials in relation to course objectives, subject matter, linguistic issues, skill, and variety and layout. To make the items easy to understand and to enhance response validity, the questionnaires were translated into participants' native language (Persian) and the translated version was then piloted with 25 students. The Cronbach alpha reliability index was calculated and the result turned out to be 0.90 which was quite acceptable. Based on the results obtained at this stage and two instructors' comments, two items of the questionnaire was modified and finalized for the final data collection. The questionnaire for instructors was the parallel form of the students' questionnaire except for some difference in the questions on the demographic information (Appendix B).

\section{Interviews}

The main reason for conducting the interviews was to elicit data regarding the interviewees' perspectives concerning: (a) the challenges in teaching and learning EAP in large overcrowded classes, (b) two criteria in the questionnaire (layout and design of their textbook, and reading skill), (c) other challenges in EAP context, and (d) their suggestions for improving the teaching and learning EAP courses in medical schools. The interview questions were designed by the researcher and were checked by the supervisor of the study for their clarity and usefulness. The interview questions are given in Appendix E.

\section{Procedure}

Data collection procedures were carried out in about 5 months (between May and September 2012). Four medical universities (as mentioned above) in which the 'Medical Terminology' textbook was the main course book and course material were selected. At the very beginning of the study, permission was gained from the heads of the language departments of the targeted universities who showed a willingness to cooperate. To enhance participation, the researcher informed the participants that their answers would be confidential and that they were not required to write or give their name at any stage of the study. The researcher also made the participants aware of the process they were supposed to go through. They were also permitted to ask any questions they had for clarification. About 200 questionnaires were distributed among the students at the four universities mentioned before, out of which 175 questionnaires were returned to the researcher.

The parallel form of questionnaire was distributed among EFL instructors at the same universities. Availability sampling was also used to gather data from the instructors. In order to ensure a high rate of return by EFL instructors, the researcher distributed and collected the questionnaires in each university in person. She visited each instructor in their office, informed them about the research project, and requested them to fill out the questionnaire. Some instructors returned the questionnaire on the same day; others returned them two to ten days later by email.

The qualitative data was gathered by semi-structured interviews. The interviews were conducted individually with 10 EFL instructors and 10 medical students who were available from the research population. Before conducting the interview, the researcher informed the participants about the aims of the interview. To reduce their fear of exposing their honest view and ensure better and reliable responses, the interviewees were assured that their opinions will be kept confidential. The permission was also gained for recording the full interview. The student subjects were interviewed in their universities and the instructors were interviewed in their offices. The interviews were conducted in the participants' native language (Persian) and all five interview questions were asked from the interviewees one by one. It took approximately 20 minutes for each person to be interviewed.

\section{Data Analysis}

After collecting the two sets of questionnaires, both questionnaires were scored on the likert scale ranging from 'excellent', 'good', 'moderate', 'weak' and 'very weak'; each column had a particular value that was 5, 4, 3, 2, and 1, respectively. Then, the Statistical Package for the Social Science (SPSS) was used for statistical analyses.

First, an independent $t$-test was run to compare the EFL instructors and medical students' perceptions of the EAP textbook they used in their classes. Moreover, a multivariate analysis of variance (MANOVA) was applied to investigate whether there were significant differences between the instructors' and students' perceptions regarding the six categories addressed by the questionnaire items. For the qualitative part of the study, content analysis was used.

\section{RESEARCH QUESTION AND HYPOTHESES}

Q1: What is the perception of Iranian medical students of their EAP textbook?

Q2: What is the perception of Iranian EFL instructors of medical EAP textbook?

Q3: Is there any significant difference between Iranian EFL instructors and medical students' perceptions of their medical EAP textbook?

Q4: Are there any significant differences between Iranian EFL instructors and medical students' perceptions of six aspects of their medical EAP textbook?

In the light of the above mentioned questions the following hypotheses were tested:

$\mathrm{H}_{01}$ : There is no significant difference between Iranian EFL instructors and medical students' perceptions of their medical EAP textbook. 
$\mathrm{H}_{02}$ : There are no significant differences between Iranian EFL instructors and medical students' perceptions of six aspects of their medical EAP textbook.

\section{INTERVIEWS QUESTIONS}

The second part of the study is related to the challenges in Iranian EAP context. The following five questions were asked from both EFL instructors and medical students:

1. What challenges do the medical students and EAP instructors face in large overcrowded classes?

2. If a textbook doesn't have a good layout and design, what challenges does it bring to teaching and learning process?

3. The main objective of EAP courses in Iran is reading skills. Do you think the book "medical terminology" fulfill this objective? If not, give your reasons? And what are your suggestions for improvements in this regard?

4. What other challenges are medical students faced with in learning EAP courses?

5. What do you suggest for improving the teaching and learning EAP courses in medical schools?

\section{Results}

\section{A. The First and Second Research (Descriptive) Questions}

As Table I shows, the mean score for the instructors was 34.46 with the standard deviation of 6.52 and the mean of the students was 32.40 with the standard deviation of 6.80 . It seems that both the students and instructors were satisfied with the textbook in general.

TABLE I

DESCRIPTIVE PERCEPTION ON MEDICAL EAP TEXTBOOK BY GROUPS

\begin{tabular}{lllll}
\hline \multicolumn{4}{l}{ DESCRIPTIVE PERCEPTION ON MEDICAL EAP TEXTBOOK BY GROUPS } \\
\hline Group & $\mathrm{N}$ & Mean & Std. Deviation & Std. Error Mean \\
\hline Instructors & 25 & 34.46 & 6.52 & 1.30 \\
Students & 175 & 32.40 & 6.80 & .51 \\
\hline
\end{tabular}

\section{B. The Third Research Question}

The third research question was: Is there any significant difference between Iranian EFL instructors and medical students' perceptions toward their medical EAP textbook?

As Table II shows, the results of the independent $t$-test $(198)=1.42, P=.156>.05, r=.10$ indicate that there was no significant difference between instructors and medical students' perceptions of their textbook. Therefore, the first nullhypothesis as there is no significant difference between Iranian EFL instructors and medical students' perception of their medical EAP textbook was supported.

TABLE II

INDEPENDENT T-TEST PERCEPTIONS ON EAP TEXTBOOK BY GROUPS

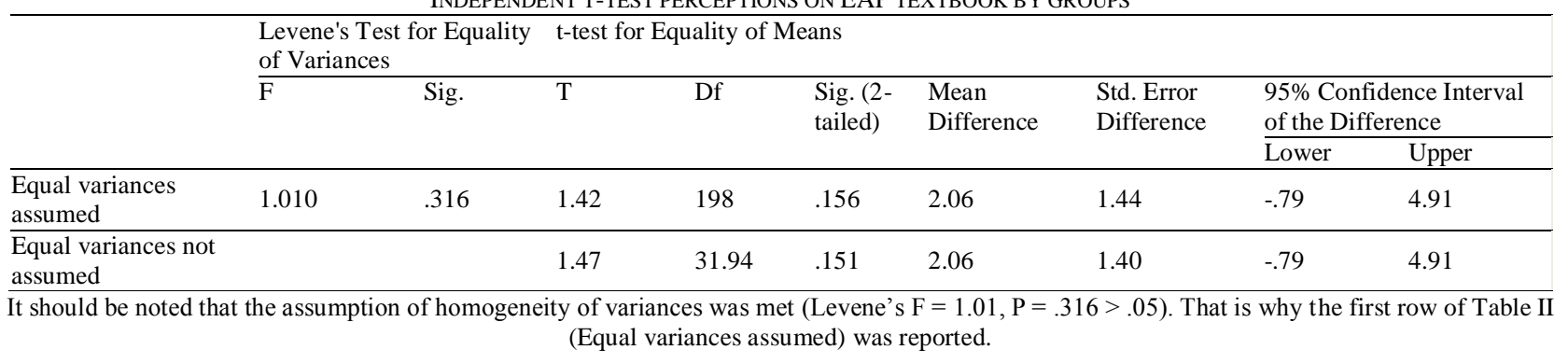

\section{The Fourth Research Question}

The fourth research question was: is there any significant difference between Iranian EFL instructors and medical students' perceptions of six aspects of their medical EAP textbook? Before answering this question and testing the hypothesis it should be mentioned that assumption of homogeneity of variances, as tested through the Levene's test was met (Levene's $F=1.01, P=.316>.05$ ).

A multivariate analysis of variances (MANOVA) was used to compare the students and instructors' perceptions of their EAP textbook in terms of six aspects, namely, practical concerns, materials in relation to course objectives, linguistic issues, subject matter, skills, and variety and layout.

The results $(F(3,193)=3.85, P=.001<.05$; Partial $\eta=.10)$ represent a moderate to strong effect size. It can be concluded that there were significant differences between the instructors and medical students' perceptions of six aspects of their EAP textbook (as Table III illustrates). Thus, the second null-hypothesis as there is no significant difference between Iranian EFL instructors' and medical students' perception of six aspects of their medical EAP textbook was rejected. 
TABLE III

Multivariate TESTS

\begin{tabular}{|c|c|c|c|c|c|c|c|}
\hline Effect & & Value & $\mathrm{F}$ & Hypothesis df & Error df & Sig. & Partial Eta Squared \\
\hline \multirow{4}{*}{ Intercept } & Pillai's Trace & .924 & 392.917 & 6 & 193 & .000 & .924 \\
\hline & Wilks' Lambda & .076 & 392.917 & 6 & 193 & .000 & .924 \\
\hline & Hotelling's Trace & 12.215 & 392.917 & 6 & 193 & .000 & .924 \\
\hline & Roy's Largest Root & 12.215 & 392.917 & 6 & 193 & .000 & .924 \\
\hline \multirow{4}{*}{ GROUP } & Pillai's Trace & .107 & 3.852 & 6 & 193 & .001 & .107 \\
\hline & Wilks' Lambda & .893 & 3.852 & 6 & 193 & .001 & .107 \\
\hline & Hotelling's Trace & .120 & 3.852 & 6 & 193 & .001 & .107 \\
\hline & Roy's Largest Root & .120 & 3.852 & 6 & 193 & .001 & .107 \\
\hline
\end{tabular}

It should be noted that the SPSS produces four F-values. In cases all of the indices are significant or non- significant one may report any of the indices.

Although the F-value of 3.85 indicates, there were significant differences between the instructors and students' perceptions of the six aspects, it is worth exploring the exact places of differences between the two groups. Based on the results displayed in Table IV, it can be concluded that:

1. There is no significant difference between the instructors and students' perceptions of their EAP textbook in terms of its practical concerns. We obtained $F(1,198)=3.42, P=.066>.05$; and Partial $\eta=.017$ which represents a weak effect size;

2. There is no significant difference between the instructors and students' perceptions of their EAP textbook in terms of its materials in relation to course objectives. We computed $F(1,198)=3.83, P=.052>.05$; and Partial $\eta=.019$ which represents a weak effect size;

3. There is no significant difference between the instructors and students' perceptions of their EAP textbooks in terms of its linguistic issues. We obtained $F(1,198)=1.84, P=.176>.05$; and Partial $\eta=.009$ which represents a weak effect size;

4. There is no significant difference between the instructors' and students' perceptions of the medical EAP textbook in terms of its subject matter. We achieved $(\mathrm{F}(1,198)=1, \mathrm{P}=.316>.05$; Partial $\eta=.005$ which represents a weak effect size; however,

5. There is a significant difference between the instructors' and students' perceptions on their EAP textbook in terms of its skills. We obtained $F(1,198)=6.38, P=.012<.05$; and Partial $\eta=.031$ which represents a weak to moderate effect size.

6. There is a significant difference between the instructors and students' perceptions on their EAP textbook in terms of its variety and layout. We achieved $F(1,198)=4.43, P=.036<.05$; and Partial $\eta=.022$ which represents a weak to moderate effect size.

TABLE IV

UNIVARIATE TESTS

\begin{tabular}{|c|c|c|c|c|c|c|c|}
\hline Dependent Variable & & Sum of Squares & $\mathrm{df}$ & Mean Square & $\mathrm{F}$ & Sig. & Partial Eta Squared \\
\hline \multirow{2}{*}{ Practical concerns } & Contrast & 292.571 & 1 & 292.571 & 3.428 & .066 & .017 \\
\hline & Error & 16899.429 & 198 & 85.351 & & & \\
\hline \multirow{2}{*}{ Materials } & Contrast & 401.786 & 1 & 401.786 & 3.835 & .052 & .019 \\
\hline & Error & 20743.714 & 198 & 104.766 & & & \\
\hline \multirow{2}{*}{ Linguistics issues } & Contrast & 104.504 & 1 & 104.504 & 1.842 & .176 & .009 \\
\hline & Error & 11231.714 & 198 & 56.726 & & & \\
\hline \multirow{2}{*}{ Subject matter } & Contrast & 63.504 & 1 & 63.504 & 1.009 & .316 & .005 \\
\hline & Error & 12463.108 & 198 & 62.945 & & & \\
\hline \multirow{2}{*}{ Skills } & Contrast & 457.143 & 1 & 457.143 & 6.383 & .012 & .031 \\
\hline & Error & 14180.857 & 198 & 71.620 & & & \\
\hline \multirow{2}{*}{ Variety and design } & Contrast & 427.215 & 1 & 427.215 & 4.437 & .036 & .022 \\
\hline & Error & 19062.554 & 198 & 96.276 & & & \\
\hline
\end{tabular}

\section{The Interviews Results}

The first interview question was: What challenges do the medical students and EAP instructors face in large overcrowded classes?

Almost all the instructors and students were of the opinions that one of the greatest challenges of medical classes is their being much overcrowded. Most of them believed that in such situation there are many challenges such as: difficulty in handling the class, noise making, teacher-centered approach with little student involvement, lack of evaluation and assessment, diversity (multi-level students in one class), ignoring the weak and silent students, little or lack of communication and interaction between student-teacher and especially student-student because of shortage of time, risk of lower achievement, lack of chance for all the students to ask their questions.

Five instructors also believed that in large classes it is difficult and time-consuming for teachers to give quizzes to the students because it takes much time and energy on the part of teachers to correct the students' papers. They also mentioned that there is no opportunity to continuously assess the students in order to determine whether they have 
understood the lesson or not. Therefore, in such situations, the teacher cannot identify the strengths and weaknesses of his teaching or get more feedback from the students.

Regarding the second question: If a textbook doesn't have a good layout and design, what challenges does it bring to teaching and learning process? Almost all the instructors and students believed that if a textbook does not have a good layout and design, it affects both students' and teachers' motivation and interest to learn or teach that book. They stated that in the medical field, it is important to use colorful and original course books. Pictures and illustrations in most cases help the students' visual memory to retain more information. The students were complaining about their textbook (MT) small font size and not having colorful pictures and illustrations (its pictures and illustrations are in black and white, while the original textbook is colorful and appropriate font size).

With regard to the third question: The main objective of EAP course in Iran is reading skills. Do you think the book 'Medical Terminology' fulfill this criteria? Most of the instructors were of the opinions that the main objective of the 'Medical Terminology' textbook (MT) is teaching medical terminology, not reading skills. They believed that this book helps the students to break the words into suffixes and prefixes, and also help them in their pronunciation. Therefore, when they are reading a text and come across with unfamiliar words, they can use their knowledge of prefixes and suffixes to guess the meaning of new words. They suggested that, a supplementary reading textbook that is based on students' needs should be added to this syllabus. However, it should be mentioned that in two universities, the "Medical Terminology" textbook was only the main book for EAP course. The students in these universities believed that the MT textbook could help them in their reading and comprehension ability. They reported that the medical students need to read medical texts, but unfortunately, even those short passages were usually ignored by the teachers and they just focused on vocabulary teaching.

About the fourth question: What other challenges are medical students faced with in EAP courses? Most of the instructors and students believed that there are different challenges in their EAP context but the major ones are: large classes, lack of appropriate materials to the students' needs, shortage of time, multi-level students in one class, insufficient knowledge of EFL instructors in EAP, shortage or lack of visual or auditorial equipments, students' low language proficiency. In addition most of the instructors referred to the lack of clear objectives in the medical field in EAP context.

With regard to the fifth question: What do you suggest for improving the teaching and learning EAP courses in medical schools? Most of the instructors suggested that at first, there is an urgent need to administer a placement test to divide the students into different levels. By doing this, it is possible to reduce the number of students in each class. Second, there should be clear objectives in EAP courses, then based on those objectives relevant materials should be designed and developed to meet the objectives. Third, EFL instructors' medical knowledge should be increased to teach EAP courses more efficiently. Fourth, the number of EAP instructors should increase. Most of the students also suggested that the number of students should be limited in each class; the time allocated to English course should be increased; medical students not only need to improve their reading ability, they also need to improve their listening, speaking, and writing ability; like instructors, they suggested that EFL instructors should increase their medical knowledge; and appropriate reading textbooks should be introduced to them.

\section{DisCUSSION AND CONCLUSION}

The first phase of this study sought to determine the perceptions of medical students and EFL instructors of their EAP textbook. In discussing the findings emanating from the two hypotheses, two important facts were revealed. First, there was no significant difference between the perceptions of the EFL instructors and medical students of their EAP textbook. Second, there were significant differences between their perceptions regarding the six aspects of the textbook.

Regarding the first and second (descriptive) questions: What are the medical students'/ EAP instructors' perceptions of their EAP textbook? The results of data revealed that, generally speaking, both the instructors and students had positive perceptions of the textbook. However, the instructors were more satisfied with the textbook than the students. The findings were inconsistent with Rahimiy's (2008) study, who found that MT textbook is not suitable for Iranian universities.

As mentioned earlier, the major areas under investigation in the questionnaires were practical concerns, materials in relation to course objectives, linguistic issues, subject matter, skills, and variety and layout. With respect to the practical concerns, materials in relation to course objectives, linguistic issues, and subject matter it was revealed that most of the instructors and students were pleased with these aspects of the textbook. However, there were disagreement between their perceptions regarding the skills and layout and variety of exercises aspects of the textbook.

Regarding the reading skill, most of the students were of the opinions that the reading passages in MT textbook have helped them in improving their reading ability. On the contrary, the instructors disagreed with the students. The instructors believed that medical students needed to read medical texts or articles based on their levels and background knowledge. Therefore, reading short simplified texts or very difficult texts could not guarantee their improvement in reading and comprehension ability.

Regarding the speaking skills, results of the data revealed that both parties did not think that the textbook helps the learners in speaking ability. The main purpose of EAP teaching in Iran is to enable the learners to read specific texts in English and to translate them into Persian even if a textbook has also focused on other skills. In many chapters of the 
Medical Terminology textbook learners are required to explain some diseases, drugs and compare them. It is important for instructors to provide students with the opportunities to take part in discussions. The relevant and interesting topics can motivate students to think and learn the language by content-based use of target language.

The last category was related to the variety of exercises and layout of the textbook. Regarding the variety of activities and exercises in the book, most of the participants were content with the variation of tasks and activities in the book, and they believed that they were challenging enough. Literature indicated that many authors like Hutchinson and Waters (1987), Garinger (2002), Grant (1987), Sheldon (1988) all included items related to variety of exercises and activities in their criteria checklist. Regarding the layout and design of MT book, there was little agreement between the two parties (as mentioned above). Most of the instructors were of the opinions that the textbook was attractive and its illustrations and photographs were motivating enough to encourage the learners to read about the subject. In contrast, the students seemed to disagree with the instructors in this regard. In the interviews, some students maintained that the original MT textbook is colorful with clear pictures and illustration and suitable font size. However, it was copied in Iran by an institute in a way that it's colorful and clear pictures and font size has been changed into small black and white pictures and a small font size. The students said that medical EAP course book should be colorful in order to be understandable. In the literature, physical appearance of a textbook is very important. McDonough and Show (2003) believed that clarity of layout is an important criterion for textbook evaluation.

Besides, the findings reveal that overcrowded classes are a major challenge in Iranian EAP context that cause many problems for instructors and learners. Over the past decades, the percentage of the students who want to study in medical field has continued to grow. This has resulted in the stuffing of classes. The problem is more obvious in EAP classes as instructors find it difficult to manage their classes communicatively.

Furthermore, large classes and lack of appropriate reading materials were not the only problems in the EAP contexts we studied. There were many other challenges in this context that need to be considered by authorities more seriously including lack of clearly articulated instructional objectives in the medical EAP context, shortage of time, insufficient knowledge of EFL instructors in EAP, students' low language proficiency, inappropriate teaching strategies, shortage or lack of laboratory equipment, and so on. Not all of these problems can be solved by teachers only. They need serious consideration by educational authorities in the first place. Better planning and budgeting are certainly needed. Even teacher variables need to be dealt with more systematically by those involved in decision-making at higher levels of our educational system.

\section{APPENDiX A. STUdents’ Questionnaire}

\section{Dear participants:}

The following questionnaire is intended for a research on perceptions of Iranian medical students of their EAP textbook (Medical Terminology). Please read the questions carefully and express your idea by selecting one of the options. The anonymity of the respondents is guaranteed.

Thank you for your cooperation.

\section{Part A: Personal Profile}

1. Gender: $\quad$ Male $\square \quad$ Female $\square$

2. Age ................

3. Field of study

4. Place of education

Part B. Please tick the box that represents your perceptions regarding the Medical Terminology textbook. 


\begin{tabular}{|c|c|c|c|c|c|}
\hline Items & excellent & good & moderate & weak & very weak \\
\hline \multicolumn{6}{|l|}{ 1. To what extent is the book available? } \\
\hline \multicolumn{6}{|l|}{$\begin{array}{l}\text { 2. To what extent can the accompanying materials be obtained in a } \\
\text { timely manner? }\end{array}$} \\
\hline \multicolumn{6}{|l|}{$\begin{array}{l}\text { 3. To what extent do the objectives of the textbook match the } \\
\text { objectives of the course? }\end{array}$} \\
\hline \multicolumn{6}{|l|}{ 4. To what extent is the text book appropriate for the audience? } \\
\hline \multicolumn{6}{|l|}{ 5. To what extent does the textbook teach basic grammatical patterns? } \\
\hline \multicolumn{6}{|l|}{$\begin{array}{l}\text { 6. To what extent does the presence of vocabularies move gradually } \\
\text { from simple to more complexes? }\end{array}$} \\
\hline \multicolumn{6}{|l|}{$\begin{array}{l}\text { 7. To what extent is the repetition of words appropriate for improving } \\
\text { more vocabulary learning? }\end{array}$} \\
\hline \multicolumn{6}{|l|}{$\begin{array}{l}\text { 8. To what extent is the presence of new vocabularies appropriate in } \\
\text { each unit? }\end{array}$} \\
\hline \multicolumn{6}{|l|}{ 9. To what extent does the textbook teach pronunciation? } \\
\hline \multicolumn{6}{|l|}{$\begin{array}{l}\text { 10. To what extent has the etymology of words been emphasized in } \\
\text { this book? }\end{array}$} \\
\hline \multicolumn{6}{|l|}{$\begin{array}{l}\text { 11. To what extent has the etymology of words improved your } \\
\text { vocabulary learning area? }\end{array}$} \\
\hline \multicolumn{6}{|l|}{$\begin{array}{l}\text { 12. To what extent does the textbook teach vocabulary learning } \\
\text { strategies? }\end{array}$} \\
\hline \multicolumn{6}{|l|}{ 13. To what extent does the subject matter interest you? } \\
\hline \multicolumn{6}{|l|}{$\begin{array}{l}\text { 14. To what extent has the ordering of material by topics been arranged } \\
\text { in a logical fashion? }\end{array}$} \\
\hline \multicolumn{6}{|l|}{$\begin{array}{l}\text { 15. To what extent has the content been provided according to your } \\
\text { needs? }\end{array}$} \\
\hline \multicolumn{6}{|l|}{$\begin{array}{l}\text { 16. To what extent has the content provided based on your background } \\
\text { knowledge? }\end{array}$} \\
\hline \multicolumn{6}{|l|}{ 17. To what extent are the materials related to your major? } \\
\hline \multicolumn{6}{|l|}{$\begin{array}{l}\text { 18. To what extent has the content been provided according to the } \\
\text { proficiency level of the students? }\end{array}$} \\
\hline \multicolumn{6}{|l|}{$\begin{array}{l}\text { 19. To what extent does the textbook help you in reading and } \\
\text { comprehension skill? }\end{array}$} \\
\hline \multicolumn{6}{|l|}{ 20. To what extent does the textbook teach speaking skill? } \\
\hline \multicolumn{6}{|l|}{$\begin{array}{l}\text { 21. Are the exercises and activities varied enough to challenge the } \\
\text { students? }\end{array}$} \\
\hline \multicolumn{6}{|l|}{$\begin{array}{l}\text { 22. To what extent does the layout and design of the textbook appear } \\
\text { attractive? }\end{array}$} \\
\hline $\begin{array}{l}\text { 23. To what extent do the photographs and illustrations in the book } \\
\text { motivate you to read about the subject? }\end{array}$ & & & & & \\
\hline
\end{tabular}

\section{APPENDIX B. InSTRUCTORS' QUESTIONNAIRE}

Dear professor,

The following questionnaire is intended for a research on perceptions of medical English language instructors of their EAP textbook (Medical Terminology). Please read the questions and express your idea by selecting one of the options. Your comments can be helpful in providing useful insights regarding providing the EAP materials in the coming semesters. The anonymity of the respondents is guaranteed.

Thank you for your cooperation

Part A. PERSONAL PROFILE

1. Age ........

2. Gender: $\quad$ male $\square \quad$ Female $\square$

3. Teaching Experience for Academic Purposes (in years):

First year $\square \quad 2-5$ years $\square \quad$ More than 5 years

4. Place of teaching: .........

Part B. Please tick the box that represents your perceptions regarding the Medical Terminology textbook. 


\begin{tabular}{|c|c|c|c|c|c|}
\hline Items & excellent & good & moderate & weak & very weak \\
\hline \multicolumn{6}{|l|}{ 1. To what extent is the book available? } \\
\hline \multicolumn{6}{|l|}{$\begin{array}{l}\text { 2. To what extent can the accompanying materials be obtained in a } \\
\text { timely manner? }\end{array}$} \\
\hline \multicolumn{6}{|l|}{$\begin{array}{l}\text { 3. To what extent do the objectives of the textbook match the } \\
\text { objectives of the course? }\end{array}$} \\
\hline \multicolumn{6}{|l|}{ 4. To what extent is the text book appropriate for the audience? } \\
\hline \multirow{2}{*}{\multicolumn{6}{|c|}{$\begin{array}{l}\text { 5. To what extent does the textbook teach basic grammatical patterns? } \\
\text { 6. To what extent does the presence of vocabularies } \\
\text { move gradually from simple to more complexes? }\end{array}$}} \\
\hline & & & & & \\
\hline \multicolumn{6}{|l|}{$\begin{array}{l}\text { 7. To what extent is the repetition of words appropriate for improving } \\
\text { more vocabulary learning? }\end{array}$} \\
\hline \multicolumn{6}{|l|}{$\begin{array}{l}\text { 8. To what extent is the presence of new vocabularies appropriate in } \\
\text { each unit? }\end{array}$} \\
\hline \multicolumn{6}{|l|}{ 9. To what extent does the textbook teach pronunciation? } \\
\hline \multicolumn{6}{|l|}{$\begin{array}{l}\text { 10. To what extent has the etymology of words been emphasized in } \\
\text { this book? }\end{array}$} \\
\hline \multicolumn{6}{|l|}{$\begin{array}{l}\text { 11. To what extent has the etymology of words improved the students' } \\
\text { vocabulary learning area? }\end{array}$} \\
\hline \multicolumn{6}{|l|}{$\begin{array}{l}\text { 12. To what extent does the textbook teach vocabulary learning } \\
\text { strategies? }\end{array}$} \\
\hline \multicolumn{6}{|l|}{ 13. To what extent does the subject matter interest your students? } \\
\hline \multicolumn{6}{|l|}{$\begin{array}{l}\text { 14. To what extent has the ordering of material by topics been arranged } \\
\text { in a logical fashion? }\end{array}$} \\
\hline \multicolumn{6}{|l|}{$\begin{array}{l}\text { 15. To what extent has the content been provided according to your } \\
\text { students' needs? }\end{array}$} \\
\hline \multicolumn{6}{|l|}{$\begin{array}{l}\text { 16. To what extent has the content provided based on the students' } \\
\text { background knowledge? }\end{array}$} \\
\hline \multicolumn{6}{|l|}{ 17. To what extent are the materials related to the students' major? } \\
\hline \multicolumn{6}{|l|}{$\begin{array}{l}\text { 18. To what extent has the content been provided according to the } \\
\text { proficiency level of the students? }\end{array}$} \\
\hline \multicolumn{6}{|l|}{$\begin{array}{l}\text { 19. To what extent does the textbook help the students in reading and } \\
\text { comprehension skill? }\end{array}$} \\
\hline \multicolumn{6}{|l|}{ 20. To what extent does the textbook teach speaking skill? } \\
\hline \multicolumn{6}{|l|}{$\begin{array}{l}\text { 21. Are the exercises and activities varied enough to challenge the } \\
\text { students? }\end{array}$} \\
\hline \multicolumn{6}{|l|}{$\begin{array}{l}22 . \text { To what extent does the layout and design of the textbook appear } \\
\text { attractive? }\end{array}$} \\
\hline $\begin{array}{l}\text { 23. To what extent do the photographs and illustrations in the book } \\
\text { motivate the students to read about the subject? }\end{array}$ & & & & & \\
\hline
\end{tabular}

\section{REFERENCES}

[1] Ansary, H. \& Babaii, E. (2002). Universal characteristics of EFL/ESL textbooks: A step towards systematic textbook evaluation. The TESL Journal 8(2). http://iteslj.org/Articles/Ansary-Textbooks/ (accessed 8/1/2012).

[2] Baleghizadeh, S. \& Rahimi, A. H. (2011). Evaluation of an ESP textbook for the students of sociology. Journal of Language Teaching and Research 2 (5), 1009-1014.

[3] Brown, J. (1995). The elements of language curriculum: A systematic approach to program development. New Yourk: Heinle and Heinle publishers.

[4] Cunningsworth, A. (1995). Choosing your coursebook. Oxford: Heinemann.

[5] Dudley-Evans, T., and St John, M. (1998). Developments in ESP: A multi-disciplinary approach. Cambridge: Cambridge University Press.

[6] Eslami-Rasekh, Z. (2010). Teachers' voice vs. students' voice: A need analysis approach to English for academic purposes (EAP) In Iran. The ELT Journal 3 (1), 2-11.

[7] Farhady, H. (2005). Reflection on and directions for ESP materials development in SAMT. In G. R. Kiany \& M. Khayamdar (eds), Proceedings of the First National ESP/EAP Conference (vol. 3). Tehran: SAMT, 2-32.

[8] Garinger, D. (2002). Textbook selection for the ESL classroom. http://www.cal.org/resources/digest/digest_pdfs/0210garinger.pdf (accessed 26/10/2012).

[9] Grant, M. (1987). Making the most of your textbook. London: Longman.

[10] Hashemi, M. R., Lamir, A. R., \& Rezaee-Namjoo, F. (2011). English for B.Sc. students of physical education in Iran: A study of perception of English needs and effectiveness of ESP textbooks. The Journal of language and literature studies 1.20, 14-22. http://dx.doi.org/10.55339/ells.vln2p14 (accessed 16/5/2012).

[11] Hutchinson, T., \& Waters, A. (1984). How communicative is ESP? The ELT Journal 38.2, 108-113.

[12] Hutchinson, T., \& Waters, A. (1987) English for specific purposes: a Learning -centered approach. Cambridge: CUP.

[13] Jones, G. M. (1990). ESP textbooks: Do they really exist? The Journal English for Specific Purposes 9.1, 89-93.

[14] Litz, D. R. A. (2005). Textbook evaluation and ELT management: a South Korean Case Study. Asian EFL Journal. http://www.asian-efljournal. com/Litz_thesis.pdf (accessed 13/5/2012).

[15] Mc Donough, J., \& Shaw, C. (2003). Materials and methods in ELT: A teacher's guide (2 $2^{\text {nd }}$ ed.). UK: Blackwell

[16] Rahimy, R. (2008). ESP, an Evaluation of available textbook. ESP world, 7(1).http//www.espwolrd.info/article_17/PDF/Ramin_Rahimy.pdf (accessed 10/7/2010). 
[17] Razmjoo, S.A. \& Raissi, R. (2010). Evaluation of SAMT ESP textbooks for the students of medical sciences. The Asian ESP Journal, 6(2), 107-140. http://www.asian-esp-journal.com (accessed 13/5/2012).

[18] Riazi, A. (2005). Features of quality EAP textbooks: Insights from literature and book reviews. In G. R. Kiany \& M. Khayamdar (eds.), Proceedings of the First National ESP/EAP conference (vol. 1).Tehran: SAMT, 35-44.

[19] Shamsaee, S., \& Shams, A. (2010). ESP teachers' pedagogical agenda vs. University students' educational ambitions: A needs analysis project. Journal of Technology \& Education 4 (4), 267-273.

[20] Sheldon, L. (1988). Evaluating ELT textbooks and materials. ELT Journal 42 (4), 237-246.

[21] Shokouhi, H. (2005). A new discourse plan for the Iranian university ESP textbooks. In G. R. Kiani \& M. Khayamdar (eds.), Proceedings of the First National ESP/EAP Conference (vol. 3). Tehran: SAMT Publication, 33-44.

[22] Soleimani, H. (2005). EAP in Iran: Drawbacks of SAMT EAP textbooks. In G. R. Kiani \& M. Khayamdar (eds.), Proceedings of the First National ESP/EAP Conference (vol. 3). Tehran: SAMT Publication, 216-229.

[23] Swales, J. (1980). ESP: The textbook problem. The ESP Journal 1 (1), 11-23.

[24] Tajeddin, Z. (2005). The theory and practice of designing a business English course. In G. R. Kiani \& M. Khayamdar (eds.), Proceedings of the First National ESP/EAP Conference (vol. 3). Tehran: SAMT Publication, 231-251.

[25] Williams, D. (1983). Developing criteria for textbook evaluation. ELT Journal 37 (3), 251-255.

Golamreza Hessamy is an Assistant Professor of TEFL at Payame-Noor University, Iran. His research interests are language assessment, teaching methodology and teaching language for academic purposes.

Masoumeh Mohebi holds an M.A. degree in TEFL from Payame-Noor University, Tehran, Iran. She has been teaching English in language institutes for five years. Her current interests are EAP and CALL. 